\title{
Enhancement of rooting and growth of bush pepper by jeevamruthum and tender coconut water
}

\author{
C.K. Thankamani*, K. Prathyusha, S. Hamza and K. Kandiannan \\ ICAR-Indian Institute of Spices Research, Kozhikode-673 012, Kerala, India
}

(Manuscript Received: 31-08-2019, Revised: 30-04-2020, Accepted: 13-05-2020)

Keywords: Bush pepper, enhancement, growth, rooting

Black pepper (Piper nigrum L.) known as the king of spices is one of the oldest spices known to the world. Presently black pepper is cultivated in 139487 ha area in India with a production of 64000 tonnes per year, but our productivity is very low $\left(458 \mathrm{~kg} \mathrm{ha}^{-1}\right)$. Since scope for area expansion is limited, especially in urban horticulture, cultivation of bush pepper in the terrace garden, coconut garden, orchards is some of the alternatives to increase the production to meet the growing demand.

Various methods to produce bush pepper from lateral cuttings have been reported (Sujatha, 2004; Sannidhi, 2018). A common problem associated with bush pepper raising has been very limited survival due to lack of root primordium in laterals resulting in poor rooting. A modified multiplication technique in bush pepper with a segment of orthotrop in laterals and treating with IBA 1000 ppm was suggested in Panniyur 1 (Sujatha, 2004) with a success rate of 74 per cent. The extraction of a large number of laterals with a segment of orthotrops for production of bush pepper required the destruction of pepper vines which will reduce the yield in the field. Another drawback of this method is the production of runner shoot from bush pepper which necessitates frequent pruning of runner shoot in pots, which is labour-consuming. Treating with IBA is inevitable for proper rooting due to presence of sclerenchymatous tissues in the shoots. Besides these, IBA is an expensive chemical which is not affordable to farmers and availability is restricted to a few chemical shops. Organic farming is gaining importance in view of sustained agriculture and maintaining ecological balance. In organic farming, planting material should be produced using organic substances. Hence proper rooting method is to be standardised using cheaper indigenous materials and also suitable sources has to be identified for collecting laterals for making bush pepper.

With these objectives, an experiment was conducted in a naturally ventilated polyhouse at ICAR-IISR, Experimental Farm, Peruvannamuzhi. The experiment was conducted on lateral shoots collected from two varieties (Panniyur 1 and Sreekara). Two sources of planting materials (vine pepper and laterals in pots) and three growthenhancing substances viz., indole butyric acid (IBA), tender coconut water (TCW) and Jeevamruthum (JA) were used as variables to constitute 13 treatments including control. Sevenyear-old black pepper varieties viz., Panniyur 1 and Sreekara grown on Ailanthus as support tree and the same maintained as bush pepper in pots (seven-year-old) were used to collect laterals. These plants were maintained with the recommended package of practices of black pepper by ICAR-IISR (Devasahayam et al., 2006). The collected one-year-old laterals from both the sources and varieties were cut into three nodes (10-15 cm long) and used for planting in polythene bags after treating with respective growth-

*Corresponding Author: tmanimidhun15@gmail.com 
enhancing substances. Polythene bags were filled with a potting mixture containing soil, FYM and granite powder in 2:1:1 proportion. Nutrient content of the potting medium was analysed (available nitrogen $688 \mathrm{ppm}$, phosphorus 54.51 ppm, potash 774 ppm and $\mathrm{pH}$ 6.4).

Jeevamruthum was prepared by mixing jaggery (250 g), gram flour (250 g), fresh cow dung $(10 \mathrm{~kg})$, fertile soil $(500 \mathrm{~g})$ from the undisturbed area and cow urine $(1 \mathrm{~L})$ with 17.5 litres of water in a drum and the slurry was stirred thrice in a day for three consecutive days. On the fourth day, jeevamruthum was taken, and laterals from both the sources were dipped for 10 minutes and planted in polybags $(25 \times 10 \mathrm{~cm}$ size $)$ filled with potting mixture. Jeevamruthum was also applied to the pottingmedia@10 mL per plant at the time of planting.

Tender coconut water was collected from 20-year-old WCT coconut tree at 7-8 months maturity. The basal end of the laterals from both the sources was dipped in tender coconut water for 10 minutes, and a similar set of laterals were dipped in 1000 ppm of IBA for 45 seconds and used for planting in polythene bags. The experiment was conducted in factorial CRD, and each treatment was replicated thrice. The number of laterals per each treatment was 15 . The data pertaining to survival rate, number of roots and growth parameters were recorded at the end of three months (Table 1). Pre and post-treatment nutrient status in the potting medium and nutrient content of leaves of laterals from both the sources before the experiment were estimated.

The maximum survival percentage of rooted cuttings was recorded by laterals collected from vine pepper (51.2\%) compared to those grown in pots $(36 \%)$ (Table 1). Standard provides support to the black pepper plant and keeps the leaves in an erect position for tapping maximum solar radiation while in potted plants branches are extending from the center to side causing mutual shade which prevents full utilisation of solar energy which might have caused less photosynthesis and less storage of food. Moreover, forage zone of vine pepper is more compared to potted plants. More NPK content in leaves of vine pepper (NPK $2.4 \%, 0.27 \%, 2.43 \%$ respectively) were observed compared to leaves in potted bush pepper (NPK 2.3\%, $0.20 \%$ and $1.49 \%$ respectively) indicating accumulation of nutrients. The growth depends on the capacity of the plants

Table 1. Effect of growth substance and source of laterals on survival and growth parameters of bush pepper

\begin{tabular}{|c|c|c|c|c|c|c|}
\hline & $\begin{array}{c}\text { Survival } \\
(\%)\end{array}$ & $\begin{array}{c}\text { No. of } \\
\text { primary } \\
\text { roots } \\
\end{array}$ & $\begin{array}{c}\text { No. of } \\
\text { secondary } \\
\text { roots }\end{array}$ & $\begin{array}{l}\text { Length of } \\
\text { primary } \\
\text { roots }(\mathrm{cm})\end{array}$ & $\begin{array}{c}\text { Height } \\
\text { (cm) }\end{array}$ & $\begin{array}{l}\text { No. of } \\
\text { leaves }\end{array}$ \\
\hline \multicolumn{7}{|l|}{ Varieties } \\
\hline Sreekara & 41.88 & 2.79 & 23.63 & 6.46 & 11.50 & 1.67 \\
\hline Panniyur 1 & 47.30 & 3.42 & 20.21 & 11.60 & 12.50 & 1.71 \\
\hline $\mathrm{CD}(0.05)$ & NS & NS & NS & 4.60 & NS & NS \\
\hline \multicolumn{7}{|c|}{ Source of laterals } \\
\hline Pot & 36.04 & 3.17 & 24.29 & 8.23 & 10.71 & 1.80 \\
\hline Tree & 51.20 & 3.04 & 19.54 & 14.89 & 13.30 & 1.58 \\
\hline $\mathrm{CD}(0.05)$ & 6.70 & NS & NS & 3.00 & NS & NS \\
\hline \multicolumn{7}{|c|}{ Growth substances } \\
\hline IBA & 43.94 & 2.00 & 16.17 & 9.03 & 12.93 & 1.80 \\
\hline TCW & 53.90 & 3.08 & 19.33 & 10.93 & 13.36 & 2.00 \\
\hline JA & 49.74 & 6.33 & 50.67 & 14.03 & 12.93 & 2.08 \\
\hline Control & 30.75 & 1.00 & 3.50 & 3.00 & 8.81 & 1.17 \\
\hline $\mathrm{CD}(0.05)$ & 8.29 & 1.32 & 9.40 & 3.60 & 1.78 & 0.50 \\
\hline
\end{tabular}


to harvest solar energy and nutrients efficiently for metabolite production. Accumulation of nutrients in laterals raised from vine pepper helped better hydrolysis and transport of nutrients to the basal portion of laterals which would have helped for better root formation and better growth.

Jeevamruthum was found to be the best treatment which produced maximum number of primary roots, number of secondary roots and length of primary roots. Jeevamruthum is a growthenhancing substance that provides all necessary nutrient requirements for growth of the crop. It contains a large number of favourable microorganisms such as nitrogen fixers, phosphorus solubilisers and actinomycetes, which convert unavailable nutrients to readily available form to plants (Palekar, 2008). Devakumar et al. (2008) reported that higher microbial load and growth hormones in jeevamruthum enhanced the soil biomass, thereby sustaining the availability of soil nutrients which ultimately resulted in better growth of the crops. This is in agreement with the findings of Rameeza and Usha (2016) who reported nutrient content in jeevamruthum as nitrogen 0.3 to 0.8 per cent, calcium $66.4 \mathrm{ppm}$, magnesium 50 to $62 \mathrm{ppm}$, zinc $0.4-7.5 \mathrm{ppm}$, and manganese 1.7-26.9 ppm. Besides nutrients, microbes in jeevamruthum are capable of producing IAA, which belongs to the auxin group (Sariga, 2018). It has been documented that auxin promoted adventitious root development of stem cuttings, through their ability to promote the initiation of lateral root primordia and to enhance transport of carbohydrates to the cutting base (Hartmann et al., 2010).

Laterals treated with tender coconut water were found to have better survival and growth among the treatments. Use of coconut water for propagation is due to the presence of cytokinin and other hormones such as auxin and gibberellins (Ma et al., 2008). According to Correa et al. (2005), auxins regulate the rooting process and carbohydrates increase the root growth. The external application of tender coconut water as growth-enhancing substances would have increased the meristematic activity and root differentiation. This was supported by the finding of Yong et al. (2009) who reported that tender coconut water (7-8 months) contains growth regulators viz., auxins, cytokinins, gibberellic acids, sugars, amino acids, potassium, chlorine, sulphur, enzymes etc., which are necessary for rooting and better growth of the plants. Tender coconut water is an important additive in tissue culture media of several plants, including orchids. The cytokinins signal the plants to divide cells into the roots and growing shoots equaling explosive growth (https://kitchenhomegardener.in.). The cytokinins, found in coconut water, support cell division and thus promote rapid growth of plants. Increased root number and root length by IBA treatment were reported in bush pepper (Sujatha et al., 2004). It was noticed that the performance of untreated lateral cuttings was less in the present study. The result conforms with the findings of Sujatha et al. (2004) who observed the lowest survival rate $(22 \%)$ in untreated Panniyur 1 cuttings propagated from laterals. The study indicated that treating three-node lateral cuttings from vine pepper with Jeevamruthum for 10 minutes and basal application of the same@10 mL or dipping basal portion of the laterals in tender coconut water for 10 minutes is beneficial for the production of organic planting material in bush pepper.

\section{References}

Correa, L.A., Paim, D.C., Schwambach, J., and Fettneto, A.G. 2005. Carbohydrates as regulatory factors on the rooting of Eucalyptus saligna Smith and Eucalyptus globules Labill. Plant Growth Regulation 45(1): 63-67.

Devasahayam, S., Anandaraj, M., Thankamani, C.K., Saji, K.V. and Jayashree, E. 2006. Black pepper. In: Major Spices-Production and Processing. (Eds.) Parthasarathy, V.A and P. Rajeev, ICAR-IISR, Calicut. pp. 15-59.

Devakumar, N., Rao, G. G. E., Shubha, S., Imrankhan, Nagaraj, and Gowda, S. B. 2008. Organic Farming and Activities of Organic Farming Research Centre. A Bulletin by Universitiy of Agricultural Sciences, Bangalore, pp. 18-27.

Hartmann, H.T., Kester, D.E., Davies Jr., F.T. and Geneve, R.L. 2011. Plant Propagation Principles and Practices. 8th Edition, Prentice-Hall, New Jersey, 840 p.

https://kitchenhomegardener.in.co. Coconut water. Miracle for plant growth posted on July 26, 2017.

Ma, Z., Ge, L., Lee, A.S., Yong, J.W., Tan, S.N. and Ong, E.S. 2008. Simultaneous analysis of different classes of phytohormones in coconut (Cocos nucifera L.) water using high performance liquid chromatography and 
liquid chromatography and tandem mass spectrometry after solid phase extraction. Analytica Chimica Acta 610(2): 274-281.

Palekar, S. 2008. The techniques of spiritual farming-Zero budget of natural farming (Part Three). published by Amol Subash Palaker, Amaravathi, Maharashtra, pp. 405-622.

Rameeza, E.M. and Usha, K.E. 2016. Influence of ageing on quality of jeevamrutham. International Journal of Applied and Pure Science and Agriculture 2(10): 158-162.

Sannidhi, H.S., Bhoomika, H.R., Priyanka, B.M., Nandish, M.S., Raviraja Shetty, G. and Ganapathi, M. 2018. Influence of plant growth promoting substances on rooting of bush pepper cuttings. International
Journal of Current Microbiology and Applied Sciences 7(9): 1685-1690.

Sariga, M. 2018. Enriched composting of agricultural wastesA comparative study. Master of Science in Food and Industrial Microbiology. Dissertation submitted to Mahatma Gandhi University, Kottayam, India, p. 81.

Sujatha, V.S., Sunil Nair, A. and Nybe, E.V. 2004. Performance of different types of planting material in the rooting and establishment of bush pepper. Indian Journal of Horticulture 61(30): 287-288.

Yong, J.W.H., Ge, L., Ng, Y.F. and Tan, S.N. 2009. The chemical composition and biological properties of coconut (Cocos nucifera L.) water. Molecules 14: 5144-5164. 